\title{
PENGUJIAN EFISIENSI PASAR BENTUK LEMAH PADA PASAR MODAL INDONESIA PERIODE 2014-2017
}

\author{
Eka Yulianti ${ }^{1}$, Dwi Jayanti² \\ Fakultas Ekonomi dan Bisnis \\ Universitas Jendral Achmad Yani \\ Email : yulianti_eka92@yahoo.com
}

\begin{abstract}
Investigate the current consumption of assets for the benefit of the future. The investment can be done by only one in the capital market which means that the investment is invested in the initial capital assets. Profit or the same value is aimed at the investor's main interest in investing not released from risk money. Such risks are inevitably uncertain about information movement in the stock market. Relevant information available can be used as a basis for making decisions when to buy shares or retain holdings of shares. In addition, information can also be a basis for consideration when to release shares or not to buy shares at all. This information relates to Efficient Market Hypothesis (HPE) which continues to research in financial markets. One of the forms of the Efficient Market (HPE) hypothesis is that market efficiency is a weak form that is examined in this study. This market efficiency form is related to random walk theory which assumes that past data is not related to present value.
\end{abstract}

Keywords : Efficient Market Hypothesis (HPE), Random Walk Theory, Run Test, and Series Correlation Test.

\section{PENDAHULUAN}

\subsection{Latar Belakang Penelitian}

Investasi adalah suatu kegiatan yang bias dilakukan untuk memperoleh pengembalian di masa yang akan datang. Investasi ini salah satunya dapat dilakukan di pasar modal yang berperan sebagai lembaga penghubung antara pihak yang kelebihan dana dengan pihak yang memerlukan dana. Pihak yang kelebihan dana inilah yang melakukan kegiatan investasi dan disebut sebagai investor. Tentunya investor bertujuan untuk memperoleh keuntungan dari hasil investasinya, namun berbagai ketidakpastian informasi yang relevan dengan pasar modal inilah yang akan menjadi risiko tidak diperolehnya keuntungan atau return. Pernyataan ini mencerminkan bahwa keuntungan atau return dan bebagai risiko yang dapat mempengaruhi variabilitas return merupakan dua hal penting yang seyogyanya menjadi pertimbangan dalam berinvestasi.

Informasi menjadi salah satu faktor penting yang harus diperhatikan oleh investor di Pasar Modal demi mewujudkan tujuannya yaitu memperoleh pengembalian investasi. Informasi relevan yang tersedia dapat digunakan sebagai dasar mengambil keputusan kapan saham akan dibeli atau dijual. Selain itu, informasi juga dapat menjadi dasar pertimbangan kapan akan melepas saham atau bahkan tidak melakukan pembelian saham. Aksi jual dan beli yang dilakukan investor berdasarkan informasi tersedia inilah yang pada akhirnya dapat mempengaruhi permintaan dan penawaran saham dan tercermin pada pergerakan harga saham dipasar modal. Adapun pergerakan harga saham di pasar modal Indonesia dapat dilihat dari perkembangan Indeks Harga Saham Gabungan (IHSG) selama periode 2017 adalah sebagai berikut.

Berdasarkan tabel 1 terlihat bahwa nilai IHSG selalu mengalami perubahan setiap bulannya. IHSG merupakan cerminan dari pergerakan seluruh harga saham di pasar modal sehingga pola perubahan IHSG tersebut dapat menjadi informasi bagi investor dalam melakukan aksi jual dan beli saham. Oleh karena itu, penelitian ini ingin membuktikan 
apakah pola perubahan return tersebut dapat digunakan oleh investor untuk memprediksi pergerakan saham di periode berikutnya. Nisar dan Hanif [1] menyatakan bahwa informasi ini dapat berkaitan dengan hipotesis pasar efisien yang beranggapan bahwa jika pasar bersifat efisien artinya harga saham mencerminkan informasi- informasi yang tersedia dan tentunya relevan. Terdapat 3 bentuk efisiensi pasar, yakni efisiensi pasar bentuk lemah, setengah kuat dan kuat.Fama [2] menyatakan jika pasar efisien dalam bentuk lemah, maka nilai-nilai historis tidak bisa digunakan untuk memperkirakan harga sekarang. Kedua, efisiensi pasar bentuk setengah kuat (semistrong form) yang berasumsi bahwa pasar dikatakan efisien dalam bentuk setengah kuat jika seluruh harga saham secara penuh mencerminkan (fullyreflect) seluruh informasi yang dipublikasikan (allpublicly available information). Ketiga, efsiensi pasar bentuk kuat (strongform) yang berasumsi bahwa pasar efisien ketika seluruh harga saham secara penuh bias mencerminkan (fully reflect) seluruh informasi yang tersedia termasuk informasi yang sifatnya privat. Ketiga bentuk efisiensi pasar ini memiliki cara pengujian yang berbeda-beda.

Tabel 1.

Perkembangan IHSG 2017

\begin{tabular}{ll}
\hline \multicolumn{1}{c}{ BULAN } & IHSG \\
\hline Januari & 5294 \\
\hline Februari & 5387 \\
\hline Maret & 5568 \\
\hline April & 5685 \\
\hline Mei & 5738 \\
\hline Juni & 5830 \\
\hline Juli & 5841 \\
\hline Agustus & 5864 \\
\hline September & 5901 \\
\hline Oktober & 6006 \\
\hline November & 5952 \\
\hline Desember & 6356 \\
\hline Sumber: finance.yahoo.com
\end{tabular}

Sumber: finance.yahoo.com, diolah kembali, 2018

Efisiensi pasar bentuk lemah merupakan bagian dari hipotesis pasar efisien yang akan dibuktikan dalam penelitian ini. Efisiensi pasar bentuk ini terkait dengan teori langkah acak (random walk theory) yang berasumsi bahwa nilai-nilai historis tidak berkaitan dengan nilai sekarang. Khajar [3] menyatakan bahwa pada teori langkah acak nilai masa lalu tidak berkaitan dengan nilai sekarang. Artinya dalam pasar bentuk lemah untuk menentukan harga suatu saham harusnya sudah tercermin pada harga saham yang berlaku (current price) dan harga saham di masa depan tidak dapat prediksi. Dalam pengujian bentuk lemah, perubahan harga di masa depan harusnya tidak berkaitan dengan perubahan harga di masa lalu. Selain itu, Khajar [3] juga menyatakan bahwa suatu pasar dikatakan efisien bentuk lemah jika harga saat ini telah mencerminkan nilai-nilai historis. Oleh karena itu, dalam bentuk lemah, data historis tidak bisa digunakan untuk menaksir harga di masa depan.

Penelitian terdahulu mengenai efisiensi pasar bentuk lemah menunjukkan hasil yang berbeda-beda. Terdapat beberapa peneliti yang membuktikan bahwa pasar modal yang diteliti efisien dalam bentuk lemah baik di pasar modal Indonesia maupun di negara lainnya, diantaranya Dosinta [4] menguji efisiensi pasar dalam keadaan krisis moneter maupun setelah krisis di pasar modal Indonesia menunjukkan bahwa baik dalam keadaan krisis maupun setelah krisis pasar modal Indonesia efisien dalam bentuk lemah tetapi tidak ada peningkatan efisiensi setelah krisis moneter. Legowo [5], meneliti efisiensi pasar baik dalam keadaan bullish maupun normal di pasar modal Indonesia menunjukkan bahwa pasar modal baik pada saat bullish maupun normal efisien bentuk lemah dan terjadi peningkatan efisiensi pada keadaan normal. Dockery, dkk [6]penelitian di bursa saham Athena dan mendukung hipotesis pasar efisien bentuk lemah. Astuti [7] menyatakan bahwa Bursa Efek Jakarta adalah efisien dalam bentuk lemah. Khajar [3] melakukan penelitian sebelum dan sesudah krisis moneter dan menunjukkan hasil bahwa pasar modal di Indonesia efisien dalam bentuk lemah. Sejalan dengan [3], Ajau, dkk [8] melakukan penelitian di pasar modal Nigeria dengan hasil bahwa pasar modal Nigeria merupakan pasar modal yang efisien dalam bentuk lemah. 
Lebih lanjut, terdapat penelitian yang tidak sejalan dengan beberapa penelitian yang telah diuraikan sebelumnya, diantaranya, Hermawan, dkk [9], penelitiannya membuktikan bahwa terdapat kritik terhadap EMH bentuk lemah dalam bentuk pola acak, namun beberapa peneliti berpendapat bahwa penentangan terhadap random walk belum tentu mencerminkan penentangan EMH bentuk lemah secara seutuhnya, karena terdapat faktor yang belum dipertimbangkan dalam model random walk seperti biaya transaksi yang pada dasarnya tentu mempengaruhi return saham. Dewi [10] menyatakan bahwa pasar modal Indonesia belum merupakan pasar yang efisien dalam bentuk lemah. Rizkianto, dkk [11] melakukan penelitian di pasar modal Indonesia dan menunjukkan bahwa pasar modal Indonesia tidak efisien dalam bentuk lemah. Selanjutnya, Nisar, dkk [1] yang melakukan pengujian efisiensi pasar bentuk lemah di pasar modal Asia selatan (India, Pakistan, Bangladesh, dan Srilanka) dan menunjukkan hasil bahwa pasar tidak efisien dalam bentuk lemah di 4 negara tersebut. Sejalan juga dengan [1], Nguyen [12] menguji efisiensi pasar bentuk lemah di pasar modal Taiwan dan menunjukkan hasil bahwa pasar modal tidak efisien dalam bentuk lemah.

\subsection{Perumusan Masalah}

1. Bagaimana pola dan korelasi pergerakan Return dan Abnormal Return pada periode 2014-2017?

2. Apakah pasar modal Indonesia efisien dalam bentuk lemah pada periode 20142017 ?

\subsection{Tujuan Penelitian}

Penelitian ini bertujuan untuk menguji efisiensi pasar bentuk lemah di pasar modal Indonesia, dimana efisiensi pasar bentuk lemah ini merupakan bagian dari teori Efficient Market Hyphothesis (EMH). Penelitian ini menggunakan return dan abnormal return sebagai variabel dan diuji keterkaitan abnormal return tersebut antar periode pengamatan. Hasil penelitian ini diharapkan dapat menjadi dasar pertimbangan bagi investor dalam hal aksi jual beli saham di pasar modal.

\section{TINJAUAN PUSTAKA}

\subsection{Efisiensi Pasar}

Efisiensi pasar saham telah menjadi bidang utama penelitian dalam ekonomi keuangan, terutama yang berkaitan denganpasar saham negara berkembang [13]. Hal ini karena teori efisiensi pasar berkaitan dengan tingkat pengembalian atau return yang dapat menarik minat investor dalam berinvestasi. Efisiensi pasar modal merupakan suatu teori yang dapat menjadi dasar pertimbangan bagi investor dalam mengelola investasinya.Teori ini beranggapan bahwa tidak ada investor yang bisa mendapatkan profit di atas rata-rata (return tak normal) [14]. Pasar efisien merupakan sebuah kondisi pasar di mana harga saham menggambarkan informasi keadaan perusahaan yang sebenarnya, sedangkan pasar tidak efisien adalah keadaan pasar di mana perilaku investor secara signifikan mempengaruhi harga sekuritas, sehingga harga saham tidak mengggambarkan keadaan perusahaan yang sebenarnya [15]. Selain itu, pasar modal juga dikatakan efisien jika harga-harga sekuritas secara lengkap dan benar menggambarkan seluruh informasi yang relevan [16]. Pasar yang efisien dapat dikategorikan sebagai pasar yang harga sahamnya menggabungkan dan menggambarkan seluruh informasi yang tersedia baik masa lalu atau pun masa sekarang [16]. Lebih lanjut, Rizkianto[11] menegaskan bahwa berkaitan dengan informasi yang tersedia tersebut sudah tercermin dalam harga sekuritas yang berarti bahwa harga sudah mewakili semua informasi. Berdasarkan definisi-definisi tersebut dapat dikemukakan bahwa pada dasarnya hipotesis pasar efisien terkait dengan bagaimana hargaharga sekuritas merespon secara cepat dan benar terhadap informasi relevan yang tersedia di pasar modal.

Berdasarkan ketiga bentuk dari informasi (informasi masa lalu, informasi masa sekarang yang sedang dipublikasikan dan informasi privat), Fama [2] menetapkan tiga jenis dari efisiensi pasar yaitu efisiensi pasar bentuk lemah (weak-form), bentuk setengah kuat (semi-strong-form) dan bentuk kuat (strong-form). 


\section{Pasar Efisien Bentuk Lemah}

Efisiensi pasar bentuk lemah menunjukkan bahwa harga sekuritas merefleksikan secara penuh informasi masa yang lalu. Hipotesis pasar efisien (HPE) bentuk terkait dengan teori langkah acak (random walktheory) yang berasumsi bahwa data masa lalu tidak berkaitan dengan nilai sekarang. Artinya untuk menetapkan harga sekuritas dalam pasar bentuk lemah, informasi masa yang lalu seharusnya sudah mencerminkan harga sekuritas yang berlaku (current price) dan harga sekuritas di masa depan tidak bisa ditetapkan [3]. Pengujian efsiensi pasar bentuk lemah seharusnya mencerminkan bahwa perubahan harga sekuritas di masa depan tidak berkaitan dengan perubahan harga sekuritas di masa lampau. Hal ini berarti bahwa pasar dikatakan efisien dalam bentuk lemah jika harga sekuritas saat ini telah mencerminkan seluruh data masa yang lalu. Oleh karena itu, dalam HPE bentuk lemah data masa yang lalu tidak bisa digunakan untuk memperkirakan harga di masa depan.

\section{Pasar Efisien Bentuk Setengah Kuat}

Efisiensi pasar bentuk setengah kuat menunjukkan bahwa secara penuh harga sekuritas merefleksikan seluruh informasi yang dipublikasikan (public information). Fama [17] mengungkapkan bahwa pasar dikatakan efisien dalam bentuk setengah kuat jika secara cepat harga sekuritas mencerminkan sepenuhnya informasi baru yang relevan dan tersedia. Informasi-informasi yang bersifat publik dapat dibagi menjadi tiga yaitu informasi baru yang terkait satu emiten, beberapa emiten (industri), atau seluruh emiten [3]. Pengujian efisiensi pasar bentuk setengah kuat berkaitan dengan seberapa cepat pasar merespon berbagai informasi yang dipublikasikan. Pasar dapat efisien secara informasi dan secara keputusan dalam bentuk setengah kuat. Pasar dikatakan efisien secara informasi dalam bentuk setengah kuat jika pasar merespon dengan cepat informasi yang dipublikasikan. Sebaliknya, jika respon pasar terjadi jauh dari sekitar pengumuman informasi yang dipublikasikan maka atau terjadi lag yang berarti bahwa secara informasi pasar tidak efisien dalam bentuk setengah kuat. Lebih lanjut, pasar dikatakan efisien secara keputusan dalam bentuk setengah kuat, jika pasar merespon dengan benar informasi yang dipublikasikan, dan begitu juga sebaliknya.Benar atau tidaknya respon terhadap informasi ini berkaitan dengan teori yang mendasari variabel yang digunakan dalam pengujian efisiensi pasar bentuk setengah kuat.

\section{Pasar Efisien Bentuk Kuat}

Efisiensi pasar bentuk kuat menunjukkan bahwa harga sekuritas merefleksikan seluruh informasi baik yang tersedia atau yang tidak tersedia di pasar modal (public and privateinformation). HPE bentuk kuat beranggapan bahwa investor tidak akan bias memperoleh abnormal return dengan menggunakan berbagai informasi baik yang tersedia atau yang tidak tersedia sehingga bentuk kuat dapat menghilangkan peristiwa yang sifatnya insidertrading yang memanfaatkan informasi orang dalam [3]. Keadaan semacam ini mencerminkan pasar modal akan seperti rumah lelang yang ideal harga selalu wajar dan tidak ada investor yang bisa mendapatkan taksiran yang lebih baik tentang harga sekuritas (18].

$$
\text { Selanjutnya, Fama }
$$
menyempurnakan ketiga bentuk efisiensi pasar tersebut menjadi efisiensi bentuk lemah menjadi suatu bentuk untuk menguji prediktabilitas return. Efisiensi bentuk setengah kuat diubah menjadi studi peristiwa (event study) dan pengujian efisiensi pasar dalam bentuk kuat disebut sebagai pengujian informasi privat (private information). Ketiga bentuk pengujian tersebut memiliki cara dan arti yang berbeda-beda.

\section{Efisiensi Pasar Bentuk Lemah}

Pengujian dari bentuk efisiensi pasar lemah berfokus pada prediktabilitas return atau harga sekuritas berdasarkan return atau harga masa lampau. Hipotesis Pasar Efisien (HPE) dikatakan benar, jika perubahan harga masa lampau tidak berkaitan dengan harga sekuritas saat ini, sehingga tidak bisa digunakan untuk memprediksi harga atau return dari sekuritas. Hal ini menimbulkan pertanyaan bahwa apakah 
informasi yang terkandung pada harga berbagai sekuritas masa lampau yang berurutan sudah mencerminkan seluruh harga saat ini. Kemudian, bagaimana keterkaitan antara harga atau return antara periode sekarang dengan periode sebelumnya. Jika HPE benar, maka perubahan harga masa lampau tidak berkaitan dengan harga sekuritas saat ini, sehingga tidak bisa digunakan untuk memperkirakan harga atau return dari sekuritas. Jogiyanto mengemukakan bahwa pasar dapat dikatakan efisien karena beberapa hal sebagai berikut:

1. Investor adalah penerima harga (price takers), yang artinya adalah investor sebagai pelaku pasar tidak dapat mempengaruhi harga sekuritas. Penentu harga demand dan supply.

2. Tersedianya informasi secara luas untuk seluruh pelaku pasar didukung dengan harga yang murah untuk mendapatkan informasi tersebut murah.

3. Informasi yang dihasilkan adalah acak dan dalam setiap pengumuman informasi bersifat random satu dengan yang lainnya. Informasi yang random berarti bahwa investor tidak bisa memperkirakan kapan emiten akan mengumumkan informasi yang baru.

4. Informasi merupakan dasar yang digunakan oleh investor secara penuh dan cepat, sehingga harga sekuritas berubah secara alami, mencerminkan informasi yang relevan untuk mencapai harga keseimbangan yang baru.

Selanjutnya, apabila asumsi-asumsi yang telah diuraikan sebelumnya tidak terpenuhi, kemungkinan pasar dikatakan tidak efisien. Jogiyanto mengemukakan bahwa pasar bisa dikatakan tidak efisien karena beberapa hal sebagai berikut:

1. Adanya sebagian kecil pelaku pasar yang dapat mempengaruhi harga sekuritas.

2. Informasi harganya mahal dan ada akses yang tidak seragam antara pelaku pasar yang satu dengan yang lain terhadap suatu informasi yang sama.
3. Informasi yang berlaku dapat ditaksir dengan baik oleh sebagian pelaku-pelaku pasar.

4. Investor adalah seorang individu yang lugas dan tidak canggih. Banyak investor yang bereaksi terhadap informasi secara lugas, karena mereka mempunyai pengetahuan yang terbatas dalam memaknai dan menginterprestasikan informasi yang diterima. Hal tersebut dikarenakan investor tidak canggih, maka mereka sering mengambil keputusan yang salah sehingga berdampak pada sekuritas bersangkutan dinilai secara tidak tepat.

Hipotesis untuk menguji bentuk lemah ini berkaitan dengan hipotesis langkah acak (random walk hypothesis). Jika harga-harga berpola acak (random walk), maka berbagai perubahan harga dari waktu ke waktu bersifat random atau independen satu sama lain. Hal ini mengindikasikan bahwa perubahan harga hari ini berkaitan dengan perubahan harga pada periode-periode sebelumnya. Teori random walk ini pertama kali dikemukakan oleh Bachelier yang berasumsi bahwa informasi baru yang menjadi dasar para analisdigunakan untuk memperkirakan nilai intrinsik akan terjadi secara independen. Selanjutnya, evaluasi terhadap informasi baru juga akan independen. Atas dasar pernyataan tersebut maka artinya perubahan harga pasar berturut-turutakan terjadi secara acak.

Lebih lanjut, Jogiyanto mengatakan bahwa pengujian dari HPE bentuk lemah ini dapat dilaksanakan dengan menggunakan metode pengujian statistik atau dengan melakukan pengujian berdasarkan aturanaturan perdagangan teknis (technical trading rules). Khajar [3] mengemukakan bahwa pengujian yang dilakukan dengan menggunakan metode statistik bisa dilakukan untuk mengukur independensi dari berbagai perubahan harga sekuritas. Jika hasil dari pengujian menghasilkan independensi berbagai harga sekuritas maka pasar dikatakan efisien dalam bentuk lemah, implikasinya adalah investor tidak bisa memanfaatkan informasi mengenai nilai-nilai historis dari variabel- 
variabel penduga (seperti misalnya harga, return, dII) untuk memperkirakan harga atau return saat ini. Pengujian statistik yang banyak digunakan untuk pengujian keterkaitan adalah pengujian hubungan variabel dengan menggunakan korelasi seri atau regresi linier dan pengujian runtun (run test). Pengujian runtun (run test) adalah suatu susunan lambang-lambang yang serupa, yang diikuti serta mengikuti lambang-lambang yang berbeda, atau tidak mengikuti atau diikuti lambang apapun [20]. Sedangkan pengujian korelasi seri dipakai untuk mengetahui seberapa besar hubungan antara harga saham periode $t$ dengan periode-periode sebelumnya.

\subsection{Return, Expected Return, dan Abnormal Return}

Tandelilin [22] menyatakan bahwa return adalah salah satu faktor yang mendorong investor untuk berinvestasi dan juga sebagai kompensasi atas keberanian investor menanggung risiko atas investasinya. Fahmi [23], menyatakan Return adalah keuntungan yang didapatkan oleh investor. Hal ini mengindikasikan bahwa return merupakan bagian penting dari dilakukannya sebuah investasi. Selanjutnya, return harapan merupakan return taksiran investor yang dapat diperkirakan dengan beberapa metode diantaranya sebagai berikut

1. Mean adjusted return adalah rata-rata return sekuritas yang dihitung dari nilai historis (pada periode sebelumnya)

2. Market adjusted return merupakanmodel yang menggunakan return pasar sebagai return harapan.

3. Market model return merupakan model yang mencerminkan hubungan antara sekuritas dengan pasar ke dalam sebuah formula regresi linear sederhana antara return sekuritas dengan return pasar.

$$
R i t=a i+\beta i . R m t+E_{i t}
$$

\section{Dimana :}

Rit : return sekuritas ke i pada periode ke $\mathrm{t}$

Rmt : returnmarket pada periode ke $\mathrm{t}$

$\mathrm{E}_{\text {it }} \quad$ : zero mean disturbance term
Lebih lanjut, abnormal return adalah salah satu variabel yang digunakan dalam penelitian ini. Bodie, et al [23] mendefinisikan bahwa abnormal return sebagai selisih atau perbedaan antara actual return dan expected return pada kinerja pasar tertentu. Abnormal return ini adalah selisih antara actual return dengan expected return (normal return). Formula yang bisa digunakan untuk menghitung abnormal return adalah sebagai berikut [22]:

$$
A R_{i t}=R_{i t}-E\left(R_{i t}\right)
$$

\section{METODE PENELITIAN}

\subsection{Desain Penelitian}

Penelitian ini dilakukan dengan menggunakan pendekatan penelitian kuantitatif dengan dua uji statistik. Uji statistik yang digunakan untuk membuktikan hipotesis pasar modal efisien dalam bentuk lemah, yaitu uji run dan uji korelasi seri dengan variabel return dan abnormal return sebagai objek penelitian.

Populasi dalam penelitian ini adalah semua saham yang termasuk ke dalam indeks Kompas 100 di Bursa Efek Indonesia. Selanjutnya teknik penentuan sampel adalah purposive sampling dengan kriteria (1) saham perusahaan yang dijadikan sampel terdaftar dalam kelompok indeks Kompas 100 secara konsisten selama periode 2014-2017 (2) saham perusahaan yang dijadikan sampel listing selama periode 2014-2017 (3) saham perusahaan yang dijadikan sampel memilki data yang lengkap dan tersedia.Penulis menggunakan dokumen-dokumen yakni data harga penutupan anggota kelompok indeks saham i pada minggu ke $t$, dan data harga penutupan Indeks Harga Saham Gabungan. Metode ini juga didukung dengan pengumpulan data dari media internet guna mencapai tujuan penelitian.

\subsection{Tahapan /Alur Penelitian}

Adapun beberapa langkah yang dilakukan dalam penelitian ini adalah sebagai berikut:

1. Mengumpulkan data-data input seperti close price dari indeks saham kompas 100 
2. Menghitung Return. Luaran dari tahap ini adalah return aktual dan expected return yang akan digunakan untuk mengitung abnormal return.

3. Menghitung Abnormal return.

4. Melakukan uji run terhadap return dan abnormal return. Luaran dari tahap ini adalah mengetahui apakah perubahan return dan abnormal return perusahaan bersifat acak (random walk) atau tidak. Jika return dan abnormal return bersifat acak maka pasar modal Indonesia terbukti efisien dalam bentuk lemah, namun jika sebaliknya maka terbukti tidak efisien dalam bentuk lemah. Adapun langkahlangkah uji run dalam penelitian ini mengadopsi yang dilakukan oleh Legowo [5] adalah sebagai berikut:

a. Bandingkan perubahan return dan abnormal return mingguan dengan return dan abnormal return mingguan sebelumnya.

b. Menentukan posisi perubahan ( turun, naik atau tetap).

c. Menghitung jumlah masing-masing tanda setiap saham

d. Menghitung runtun sesungguhnya (R) periode yang diteliti

e. Menghitung runtun harapan (expected run), untuk seluruh tanda dengan formula:

$$
m=N(N+1)-\sum_{i=1}^{3} n_{i}^{2} / N
$$

f. Menghitung standar deviasi dengan rumus:

$\sigma_{m}=\sqrt{\sum_{i=1}^{3} n_{i}^{2}\left(\sum_{i=1}^{3} n_{i}^{2}+N(N+1)\right)-2 N \sum_{i=1}^{3} n_{i}^{3}-N^{3} / N^{2}(N-1)}$

g. Menghitung Z, karena perubahan mengikuti atau menyesuaikan dengan distribusi normal (karekteristik teori keacakan/ random walk) dengan rumus:

$$
Z=\frac{(R \pm 1 / 2)-m}{\sigma_{m}}
$$

h. Mengevaluasi dan menentukan hasil pengolahan data berdasarkan nilai $Z$ yang didapat

i. Melakukan uji keacakan (randomness test). Jika nilai prob value lebih besar dari a, maka pola perubahan return dan abnormal return bersifat acak.

5. Melakukan uji korelasi seri. Uji ini dipakai untuk mengetahui seberapa kuat hubungan antara return dan abnormal return periode $t$ dengan periode $t$ sebelumnya. Adapun langkah-langkah uji korelasi seri dalam penelitian ini mengadopsi yang dilakukan oleh Legowo [5] yang menggunakan variabel harga saham sebagai objeknya sebagai berikut:

a. Menghitung $x$ dan $y$ dengan formula:

$$
\begin{gathered}
\bar{X}=\sum_{i=1}^{n} X_{i} / N . \\
\bar{Y}=\sum_{i=1}^{n} Y_{i} / N
\end{gathered}
$$

b. Menghitung $\left(X_{i}-\bar{X}\right)$ an $\quad 1\left(Y_{i}-\bar{Y}\right)^{2}$.

c. Menghitung besar koefisien korelasi seri (r) dengan formula :

$$
r_{t}=\frac{\sum\left(X_{i}-\bar{X}\right)\left(Y_{i}-\bar{Y}\right)}{\sqrt{\left(\sum\left(X_{i}-\bar{X}\right)^{2}\right)\left(\sum\left(Y_{i}-\bar{Y}\right)^{2}\right)}}
$$

d. Menentukan a

e. Menghitung nilai $Z$, dengan formula:

f. $\quad Z=0,5 \ln \frac{(1+r)}{(1-r)}$ abilitas besar probvalue lebih besar dari a, maka hipotesis yaitu tidak ada korelasi diterima.

\section{HASIL PENELITIAN DAN PEMBAHASAN \\ 4.1 Rata-rataReturn SahamPeriode 2014- 2017}

Salah satu variabel yang digunakan untuk menguji efisiensi pasar bentuk lemah adalah return saham. Berikut ini disajikan rata- 
rata return saham dari saham-saham perusahaan yang dijadikan sampel selama periode 2014-2017 sebagai berikut:

Gambar 1.

Rata-rata Return Saham 2014

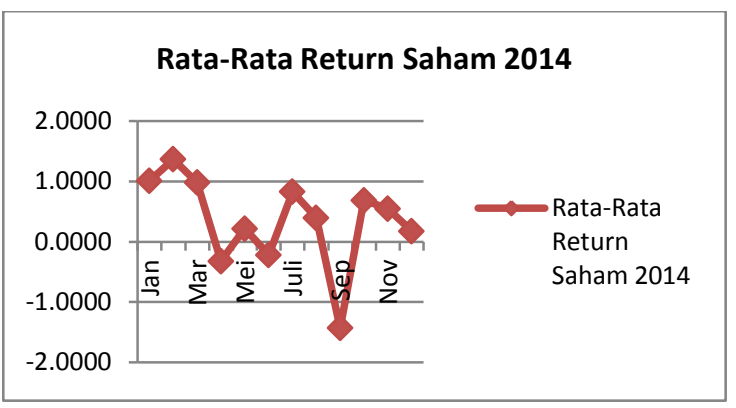

Gambar 2.

Rata-rata Return Saham 2015

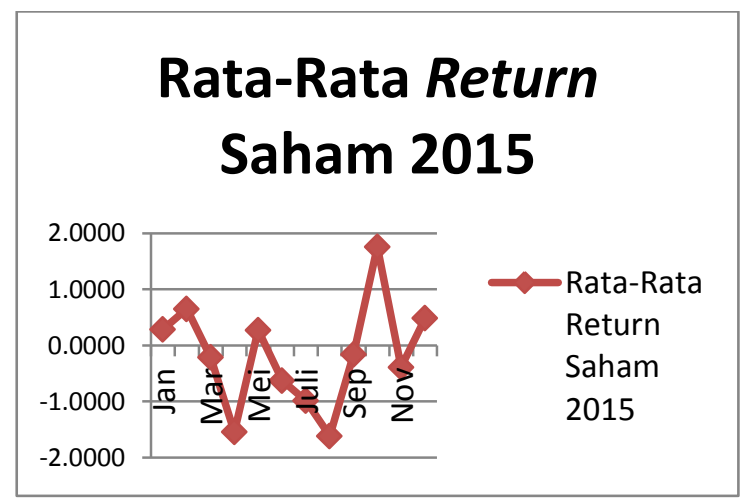

Gambar 3.

Rata-rata Return Saham 2016

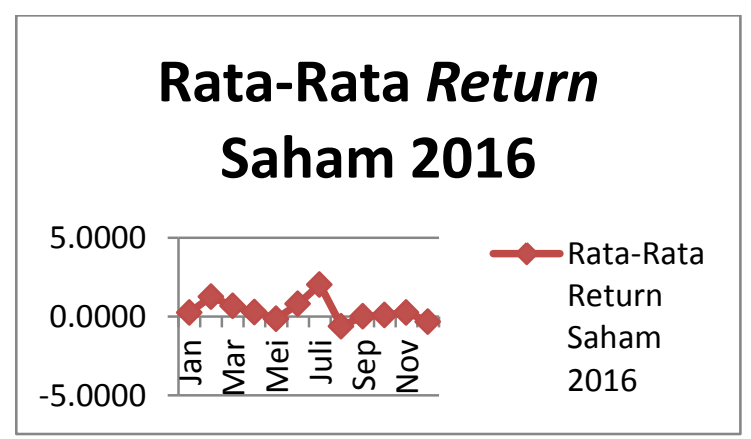

Gambar 4.

Rata-rata Return Saham 2017

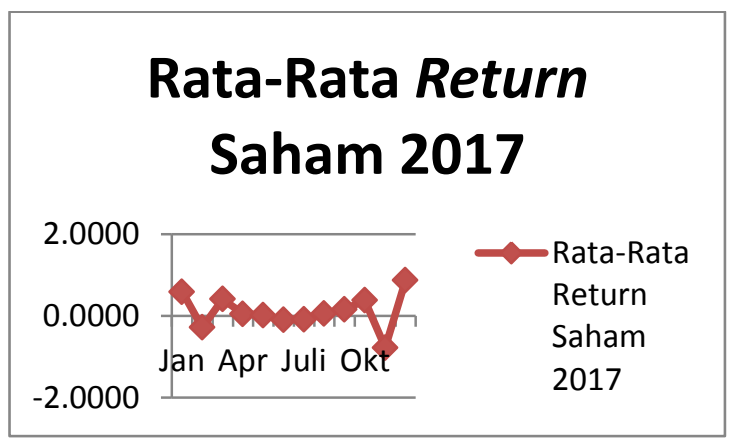

Berdasarkan gambar $1 \mathrm{~s} / \mathrm{d} 4$ terlihat bahwa rata-rata return saham selama periode 2014-2017 berfluktuasi. Pada tahun 2014 nilai terendah rata-rata return saham adalah -2.196, nilai tertinggi adalah 3.814 , sedangkan nilai rata-ratanya adalah 0.359 . Selanjutnya, tahun 2015 dan 2016 nilai terendah berturut-turut adalah -5.053 dan -3.629 , sedangakan nilai tertinggi berturut-turut adalah 9.023 dan 3.584 . Nilai rata-rata pada tahun 2015 dan 2016 berturut-turut adalah -0.193 dan 0.347. Pada tahun 2015 dan 2016 pergerakan return saham ini lebih fluktuatif dibandingkan dengan tahun 2014 dan 2017. Pada tahun 2017 pergerakan rata-rata return saham cenderung stabil yakni, nilai terendah adalah -1 . 30, nilai tertinggi adalah 1.61 , dan nilai rata-rata adalah 0.10 .

\subsection{Return Pasar Periode 2014-2017}

Variabel lain yang digunakan dalam penelitian ini adalah abnormal return, untuk mencari abnormalreturn maka komponen expected rurn perlu dicari. Penelitian ini menggunakan Market adjusted return yang merupakanmodel dengan menggunakan return pasar sebagai return harapan. Adapun return pasar selama periode penelitian adalah sebagai berikut: 
Gambar 5.

Return Pasar 2014

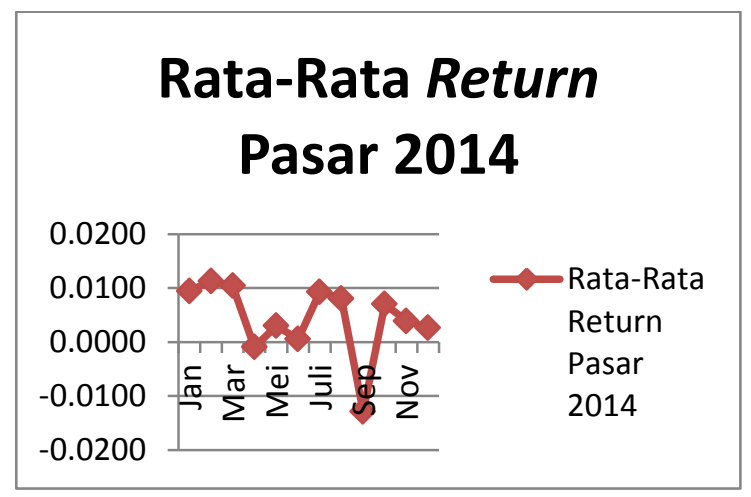

Gambar 6.

Return Pasar 2015

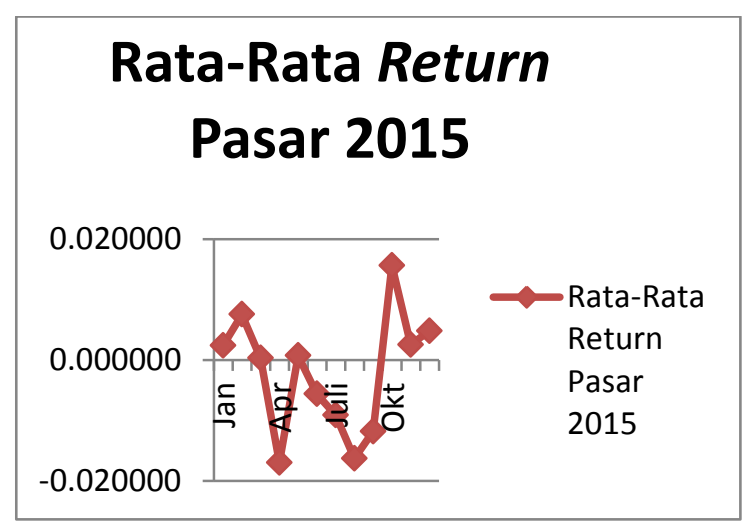

Gambar 7.

Return Pasar 2016

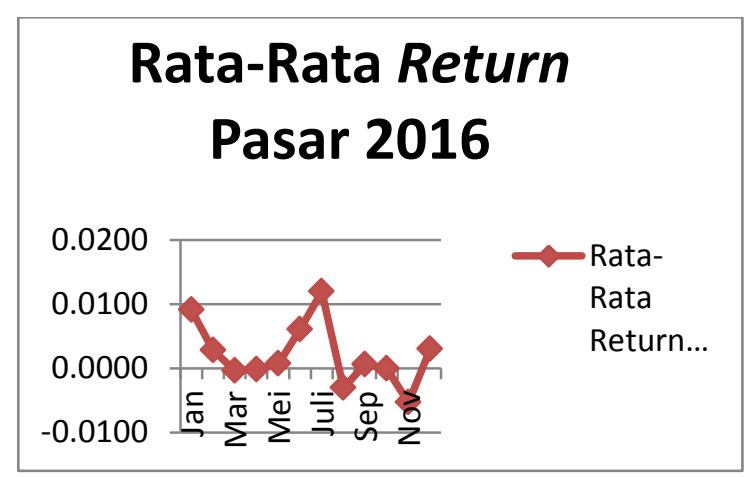

Gambar 8.

Return Pasar 2014

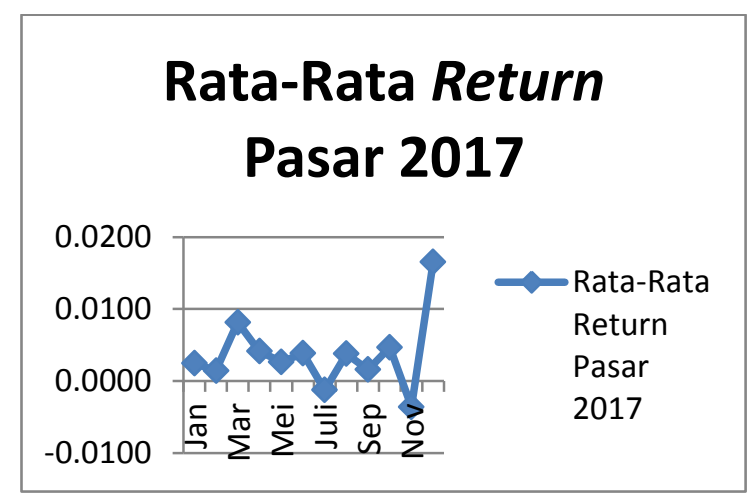

Berdasarkan gambar $5 \mathrm{~s} / \mathrm{d} 8$ terlihat bahwa return pasar juga berfluktuasi. Pada tahun 2014-2017 nilai terendah return pasar berturut-turut adalah $-0.03657,-0.00224$, 0.03898 , dan -0.01896 . Selanjutnya nilai tertinggi berturut-turut adalah 0.04114, 0.09068, 0.05351, dan 0.02778.Lebih lanjut nilai rata-rata berturut-turut adalah 0.00427 , $0.0642,0.00236$ dan 0.00361 .

\subsection{Rata-rata Abnormal return Periode 2014-2017}

Seperti yang telah diuraikan sebelumnya bahwa variabel lain yang digunakan selain return adalah abnormal return. Adapun nilai abnormal return selama periode penelitian adalah sebagai berikut:

Gambar 9.

Rata-rata Abnormal Return 2014

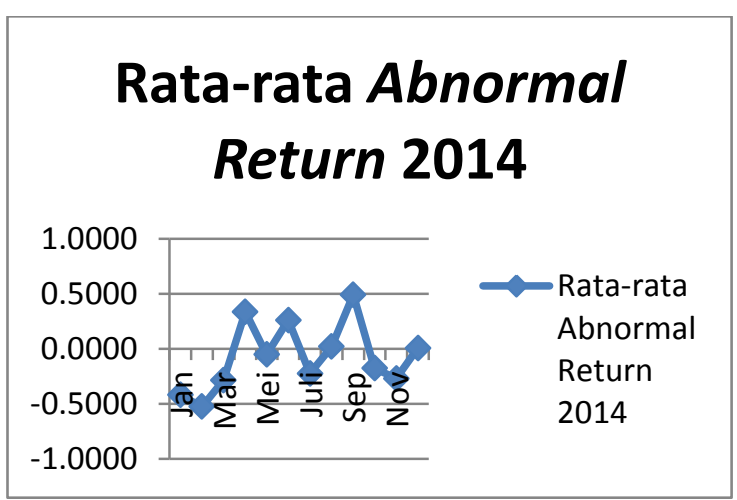


Gambar 10.

Rata-rata Abnormal Return 2015

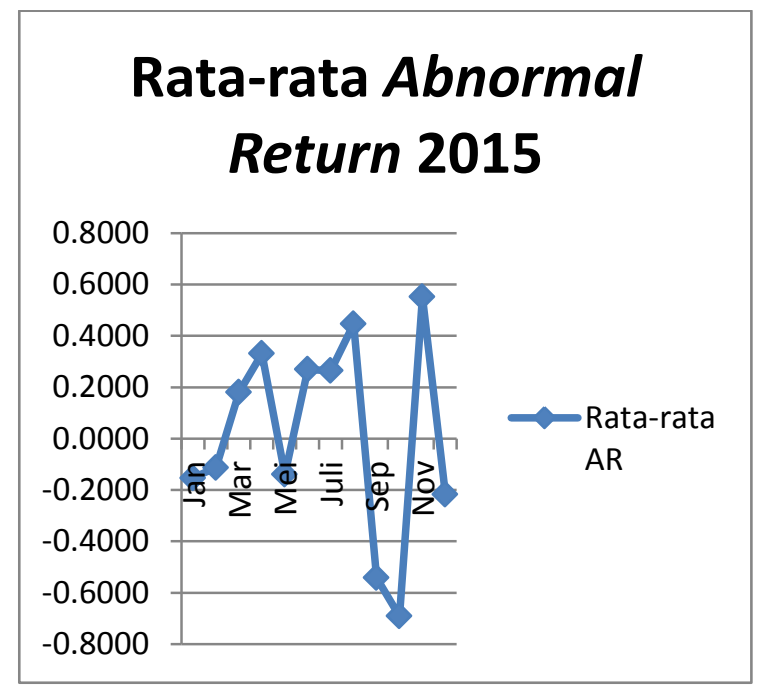

Gambar 11.

Rata-rata Abnormal Return 2016

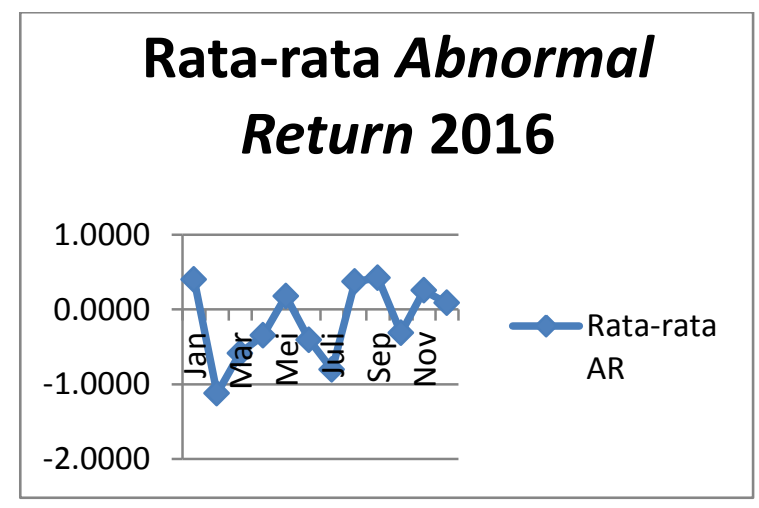

Gambar 12.

Rata-rata Abnormal Return 2017

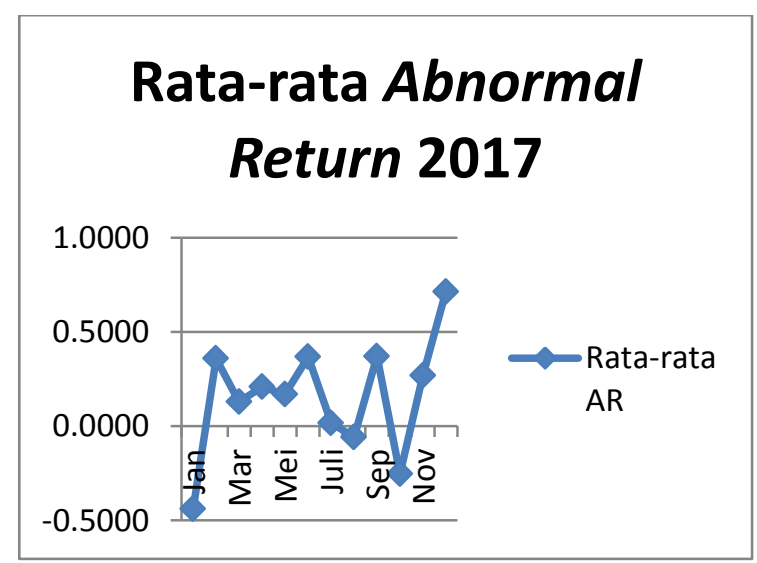

Berdasarkan Gambar 9 s/d 12 terlihat bahwa nilai rata-rata abnormal return berfluktuasi. Pada tahun 2014 hingga 2017 nilai tertinggi rata-rata abnormal return berturut-turut adalah 1.6500, 1.3511, 1.2294, dan 1.8980. Selanjutnya nilai terendah berturut-turut adalah $1.3819, \quad-2.9744, \quad-3.0438$, dan 0.6939 .Sedangkan, nilai rata-ratanya berturutturut adalah $0.0693,0.0305,-0.1821$, dan 0.1330 .

\subsection{Hasil Uji Normalitas Data}

Pengujian efisiensi pasar bentuk lemah dilakukan melalui uji run dan uji korelasi seri. Sebelum melakukan kedua pengujian tersebut maka dalam penelitian ini data melalui proses uji normalitas. Data yang diuji normalitasnya adalah data return dan abnormal return selama periode analisis yakni 2014-2017. Dalam penelitian ini normalitas data diuji dengan menggunakan analisis statistik (uji one sample kolmogorov smirnov). Adapun hasil uji normalitas data adalah sebagai berikut:

Tabel 2.

Hasil Uji Normalitas Data

\begin{tabular}{clc}
\hline TAHUN & \multicolumn{1}{c}{ VARIABEL } & P:Value \\
\hline 2014 & Return & 0.977 \\
\hline & Abnormal Return & 1.000 \\
\hline 2015 & Return & 0.576 \\
\hline & Abnormal Return & 0.812 \\
\hline 2016 & Return & 0.877 \\
\hline & Abnormal Return & 0.232 \\
\hline 2017 & Return & 0.987 \\
\hline & Abnormal Return & 0.431 \\
\hline
\end{tabular}

Sumber :Hasil Pengolahan Data, 2018

Berdasarkan tabel 2 pengujian normalitas pada variabel return dan abnormal returnselama periode 2014-2017 tersebut berdistribusi normal karena hasil dari kolmogorov smirnov lebih besar dari taraf signifikansi yang ditentukan yakni $5 \%$.

\subsection{Hasil Uji run}

Uji run dalam penelitian ini dilakukan untuk mengetahui apakah pasar efisien atau tidak dalam bentuk lemah. Uji run dilakukan untuk variabel return dan abnormal return. Adapun hasil uji run untuk kedua variabel tersebutdapat dilihat pada tabel 3 dan 4 sebagai berikut: 
Tabel 3.

Hasil Uji Run pada Return Periode 20142017

\begin{tabular}{cccc}
\hline TAHUN & $\begin{array}{c}\text { ASSYMP. } \\
\text { SIG } \\
\text { VALUE }\end{array}$ & $\begin{array}{c}\text { SIG. } \\
\text { LEVEL }\end{array}$ & KETERANGAN \\
\hline 2014 & 0.812 & 0.05 & random \\
\hline 2015 & 0.567 & 0.05 & random \\
\hline 2016 & 0.423 & 0.05 & random \\
\hline 2017 & 0.567 & 0.05 & random \\
\hline
\end{tabular}

Sumber :Hasil Pengolahan Data, 2018

Tabel 4.

Hasil Uji Run pada Abnormal Return Periode 2014-2017

\begin{tabular}{cccc}
\hline TAHUN & $\begin{array}{c}\text { ASSYMP. } \\
\text { SIG } \\
\text { VALUE }\end{array}$ & $\begin{array}{c}\text { SIG. } \\
\text { LEVEL }\end{array}$ & KETERANGAN \\
\hline 2014 & 0.401 & 0.05 & random \\
\hline 2015 & 0.567 & 0.05 & random \\
\hline 2016 & 0.299 & 0.05 & random \\
\hline 2017 & 0.702 & 0.05 & random \\
\hline
\end{tabular}

Sumber :Hasil Pengolahan Data, 2018

Berdasarkan hasil uji yang ditunjukkan pada tabel 3 dan 4 terlihat bahwa seluruhnya memiliki nilai $P$ : value lebih besar dari tingkat signifikansi $5 \%$. Hal ini berarti bahwa baik variabel return maupun abnormal return selama periode 2014-2017 mengikuti pola acak atau random. Hasil ini juga mengindikasikan bahwa, informasi pergerakan saham di masa lalu tidak bisa dipakai sebagai bahan pertimbangan untuk berinvestasi di masa depan. Fama [2] mengatakan bahwa efisiensi pasar bentuk lemah beranggapan bahwa data-data historis tidak berkaitan dengan nilai saat ini. Artinya, untuk menetapkan harga sekuritas dalam pasar bentuk lemah, informasi historis seharusnya sudah tercermin pada harga sekuritas yang berlaku (current price) dan harga sekuritas di masa depan tidak bisa ditetapkan [3].

Selain itu, hasil dari pengujian run yang random juga menunjukkan bahwa pasar efisien dalam bentuk lemah.Pernyataan ini didukung oleh Fama [2] yang menyebutkan bahwa pasar dikatatakan efisien dalam bentuk lemah jika pergerakan saham berpola random atau acak.Oleh karena itu, dalam hipotesis pasar efisien bentuk lemah data historis tidak bisa dipakai untuk memperkirakan harga di masa depan.

\subsection{Hasil Uji Korelasi Seri}

Uji korelasi seri dipakai untuk mengetahui seberapa kuat hubungan antara return dan abnormal return periode $t$ dengan periode t sebelumnya. Adapun hasil uji korelasi seri pada variabel return dan abnormal return dapat dilihat pada tabel 5 dan 6 sebagai berikut:

Tabel 5.

Hasil Uji Korelasi Seri pada Return Periode 2014-2017

\begin{tabular}{ccc}
\hline TAHUN & CORRELATION & KETERANGAN \\
\hline 2014 & 0.069 & Korelasi rendah \\
\hline 2015 & -0.121 & Korelasi rendah \\
\hline 2016 & 0.081 & Korelasi rendah \\
\hline 2017 & -0.136 & Korelasi rendah \\
\hline
\end{tabular}

Sumber : Hasil Pengolahan Data, 2018

Tabel 6.

Hasil Uji Korelasi Seri pada Abnormal Return Periode 2014-2017

\begin{tabular}{ccc}
\hline TAHUN & CORRELATION & KETERANGAN \\
\hline 2014 & 0.082 & Korelasi rendah \\
\hline 2015 & -0.015 & Korelasi rendah \\
\hline 2016 & 0.141 & Korelasi rendah \\
\hline 2017 & -0.122 & Korelasni rendah \\
\hline
\end{tabular}

Sumber : Hasil Pengolahan Data, 2018

Berdasarkan tabel 5 dan 6 dapat dikatakan bahwa baik pada variabel return maupun abnormal returnkorelasi antar return dan antar abnormal return tiap periode adalah rendah. Hal ini mengindikasikan bahwa pergerakan saham antar periode memiliki hubungan yang rendah. Hasil pengujian korelasi juga relevan dengan hasil uji run yang menunjukkan bahwa pergerakan saham yang dilihat dari return dan abnormal return berpola acak. Pengujian ini juga membuktikan bahwa pasar efisien dalam bentuk lemah.

Penelitian-penelitian terdahulu yang mendukung efisiensi pasar bentuk lemah diantaranya adalah Dosinta [4] melakukan uji efisiensi pasar baik dalam keadaan krisis moneter maupun paska krisis di pasar modal Indonesia dengan hasil penelitian menunjukkan 
bahwa pasar modal baik dalam keadaan krisis maupun paska krisis adalah efisien dalam bentuk lemah tetapi tidak terjadi perbaikan atau peningkatan efisiensi paska krisis moneter. Legowo [5], meneliti efisiensi pasar baik dalam keadaan bullish maupun normal di pasar modal Indonesia menunjukkan bahwa pasar modal baik dalam keadaan bullish maupun normal dikatakan efisien bentuk lemah dan terjadi perbaikan efisien pada keadaan normal. Sejalan dengan [4] dan [5], Dockery, dkk [6] melakukan penelitian di bursa saham Athena dengan menggunakan tes varian rasio untuk mengkaji adanya rata-rata ketergantungan antara perubahan harga saham dan hasilnya mendukung hipotesis pasar efisien bentuk lemah. Selanjutnya, Astuti [7] menggunakan uji run dan Kolmogorov smirnov dengan ILQ 45 sebagai subjeknya menyatakan bahwa Bursa Efek Jakarta efisien dalam bentuk lemah.Khajar [3] melakukan penelitian sebelum dan sesudah krisis moneter menunjukkan hasil bahwa pasar modal Indonesia efisien dalam bentuk lemah.Sejalandengan [3], Ajau, dkk [8] melakukan penelitian di pasar modal Nigeria menggunakan uji run dan korelasi seri dengan hasil bahwa pasar modal Nigeria efisien dalam bentuk lemah.

Hasil-hasil pengujian dalam penelitian ini baik dengan menggunakan uji run maupun korelasi seri menunjukkan bahwa pasar modal efisien dalam bentuk lemah. Hal ini berarti bahwa pergerakan sekuritas di pasar modal Indonesia dengan Kompas 100 sebagai subjek penelitian adalah bersifat random walk. Artinya, pergerakan sekuritas di masa lalu tidak berkaitan dengan pergerakan pada saat ini dan masa depan. Dengan demikian, investor tidak dapat menggunakan pola-pola return atau pergerakan saham masa lalu sebagai pertimbangan investasinya.

\section{SIMPULAN DAN SARAN}

\subsection{SIMPULAN}

Berdasarkan pembahasan yang telah diuraikan sebelumnya, maka dapat disimpulkan bahwa:

1. PergerakanReturndan abnormal return mengikuti pola random selama peiode 2014-2017.
2. Return dan abnormal return antar periode analisis memiliki korelasi yang rendah selama periode 2014-2017.

3. Pasar efisien dalam bentuk lemah selama periode 2014-2017, sehingga investor tidak dapat menggunakan pergerakan saham di masa lalu sebagai pertimbangan investasinya.

\subsection{SARAN}

Berdasarkan kesimpulan pada sub bab sebelumnya, maka saran yang dapat diberikan adalah sebagai berikut:

1. Saran Untuk Investor/calon investor

Pasar efisien dalam bentuk lemah berarti informasi pergerakan saham di masa lalu tidak dapat digunakan sebagai bahan pertimbangan untuk berinvestasi di masa yang akan datang. Oleh karena itu, investor sebaiknya tidak menggunakan data masa lalu tersebut sebagai dasar menentukan strategi investasinya.

2. Saran Untuk Penelitian Selanjutnya Saran penulis untuk penelitian selanjutnya adalah sebagai berikut:

a. Peneliti selanjutnya sebaiknya memperpanjang periode penelitian agar hasil penelitian lebih dapat digeneralisir.

b. Penelitian selanjutnya hendaknya menggunakan tambahan metode lain seperti variance ratio test agar hasil menjadi lebih akurat.

c. Peneliti selanjutnya hendaknya melakukan analisis berdasarkan dua kategori yakni pada saat pasar dalam keadaan bullish dan bearish market.

\section{DAFTAR PUSTAKA}

Nisar, Saqib \& Hanif, Muhammad. 2012. Testing Weak Form Of Efficient Market Hypothesis:

Empirical Evidence From South-Asia. World Applied Sciences Journal 17 (4): 414427, ISSN 1818-4952, Pakistan

Fama, E., 1970. Efficient Capital Markets: A Review Of Theory And Empirical Work. The Journal Of Finance, 25: 383-417

Khajar, Ibnu. 2008. Pengujian Efisiensi Dan Peningkatan Efisiensi Bentuk Lemah Bursa Efek Indonesia Pada Saat Dan 
Sesudah Krisis Moneter Pada SahamSaham Lq-45. Jurnal Manajemen Teori dan Terapan | Tahun 1, No.3. Universitas Sultan Agung Semarang.

Dosinta. 2004. Pengujian Efisiensi Pasar Bentuk Lemah: Untuk Melihat Peningkatan Efisiensi Dalam Dua Periode Yang Berbeda. Tesis FE-UGM. Yogyakarta.

Legowo. 1995. Efisiensi Pasar Modal: Perbandingan Pada Dua Periode Yang Berbeda Dalam Pasar Modal Indonesia. Tesis FE-UGM. Yogyakarta.

Dockery, D. Vergari, D. \& Vergari, F. 2001. Explaining The Behaviour of StockPrices In An Emerging Market: An Empirical Analysis Of The Greek Stock. Managerial Finance Vol.27

Astuti, Santi Puspita. 2008. Analisis Pasar Modal Bentuk Lemah Pada Bursa Efek Jakarta. Tesis. Universitas Diponegoro, Semarang.

Ajao,M. Gabriel\& Osayuwu, Richard. 2012. Testing The Weak Form Of Efficient Market Hypothesis In Nigerian CapitalMarket. Accounting And Finance Research. Vol. 1, No. 1

Hermawan, Moudy \& Subiyantoro, Heru. 2006. Pengujian Hipotesis Pasar Efisien Bentuk Lemah Pada Pasar Modal Di Indonesia: Sebuah Catatan Empiris. Jurnal Keuangan Vol.4 No.1

Dewi, Kumala Retno. 2009. Pengujian Efisiensi Pasar Modal Melalui Evaluasi Pegerakan Indeks LQ-45 di Bursa Efek Jakarta. Skripsi. Universitas IslamNegeri Syarif Hidayatullah, Jakarta

Rizkianto, G. Denaya \& Surya, A. Budhi. 2014. Testing The Efficient Market Hypothesis On Weak And SemistrongForm In The Indonesian Stock Market. Journal OfBusiness And ManagementVol. 3, No.2, 2014: 179190. Institut Teknologi Bandung, Indonesia

Nguyen, Chu V, dkk. 2012. Testing The WeakForm Efficient Market Hypothesis: Using Panel Data From The Emerging Taiwan Stock Market. International Journal Of Business And Social
Science Vol. 3 No. 18. University Of Houston-Downtown.

Rapuluchukwu,E.U. 2010. The Efficient Market Hypothesis:Realities From The Nigerian Stock Market"Global JournalOf Finance And Management 2(2):321-331.

Khan, A.Q \& Ikram,Sana. 2010. Testing SemiStrong Form of Efficient Market Hypothesis In Relation To The Impact Of Foreign Institutional Investors' (FIl's) Investments On Indian Capital Market. International Journal of Trade, Economics And Finance, Vol.1, No.4. India.

Pedersen, L. H. (2015). Efficiently Inefficient: How Smart Money Invests and Market Prices are Determined. United Kingdom: Priceton University Press.

Granger, Clive W.J. 2004. Efficient Market Hypothesis And Forecasting. International Journal Of Forecasting. 20.15.27. Departmen Of Economics. University Of California San Diego, USA

Fama, Eugene F. 1991. Efficient Capital Market II. Journal Of Finance. Desember. 66(5), Pp:1-21.

Husnan, Suad. 2005. Dasar-Dasar Teori Portofolio Dan Analisis Sekuritas. Yogyakarta : YKPN,

Jogiyanto. 2014. Teori Portofolio Dan Analisis Investasi. Yogyakarta: BPFE.

Bachelier, L., 1900. Theorie De La Speculation, Reprinted In Paul H. Cootner (Ed). The Random Character of Stock Market Prices. Cambridge, Mass, The M.I.T. Press, 1964: 17-78.

Siegel. 1994. Statistik Nonparametrik Untuk IImu-IImu Sosial. PT Gramedia PustakaUtama. Jakarta.

Fahmi, Irham dan Yovi Lavianti, H. 2011. Teori Portofolio dan Analisis Investasi: Teori dan Soal Jawab. Cetakan Kedua. Bandung: Alfabeta.

Tandelilin, Eduardus. 2010. Analisis Investasi dan Manajemen Portofolio. Edisi ke Lima. BPFE, Yogyakarta.

Bodie, Z, Kane A dan Maarcus, A.J. 2008. Investments: Investasi. International Edition. (Z.Dalimunthe,trans) Jakarta:salemba empat. 